\title{
DETERMINING FACTORS OF JUMP SERVICE VOLLEYBALL IN THE STUDENT ACTIVITY UNIT OF VOLLEYBALL MUHAMMADIYAH UNIVERSITY OF SURAKARTA
}

\author{
Gatot Jariono $^{1 *}$, Haris Nugroho ${ }^{2}$, Djoko Nugroho ${ }^{3}$, Sae Dikdaya Nyatara ${ }^{4}$, Tunjung \\ Marganingrum $^{5}$, Dewi Setiawati ${ }^{6}$ \\ ${ }^{145}$ Sports Education, Teacher Training and Education Faculty, Universitas Muhammadiyah \\ Surakarta, Sukoharjo, Indonesia \\ ${ }^{2}$ Sports Training Education, Faculty of Sports, Universitas Sebelas Maret Surakarta, Surakarta, \\ Indonesia \\ ${ }^{3}$ Physical Education Sports, Health and Recreation, Faculty of Sports, Universitas Sebelas \\ Maret Surakarta, Surakarta, Indonesia \\ ${ }^{6}$ Center for the Development and Empowerment of Educators and Education Personnel of \\ Physical Education and Counseling Guidance, PPPPTK Penjas and BK Parung, Bogor,
} Indonesia

\section{Article Info}

Article History :

Received : December 2021 Revised : December 2021 Accepted : December 2021 Available online : December 2021

Keywords:

Determining factors, Jump Service, Volleyball,

\begin{abstract}
The purpose of this study was to determine the determinants of serviceability in male athletes from the volleyball student activity unit at the University of Muhammadiyah using a factor analysis approach in terms of anthropometric and physical condition aspects. The population in this study were all male students of the UMS volleyball student activity unit, with a total of 40 people. The sampling technique used is purposive random sampling. data collection techniques with tests and measurements. The method used in this research is a quantitative research approach using a confirmatory analysis design. Data analysis using SPSS software version 22 and using Kaiser-Meyer-Olkin test and Bartlett's test.The results showed that anthropometric and physical condition factors that determine the sport's ability of male athletes in the student activity unit of the Muhammadiyah University of Surakarta consist of seven factors, namely height, arm length, leg muscle power, abdominal strength, arm muscle power, eye-hand coordination muscles. and flexibility of the stick. However, this research is only limited to the male sample group, furthermore, it is recommended to involve female samples and social environmental factors and are related to the increase in volleyball jump service.
\end{abstract}

\footnotetext{
Corresponding address : Jalan A. Yani, Pabelan,Tromol Pos 1,

Pabelan, Surakarta 57102

*Corresponding email: gj969@ums.ac.id

ISSN 2685-6514 (Online)

ISSN 2477-331X (Print)
} 


\section{INTRODUCTION}

Volleyball is one of the sports that are widely loved by all levels of society in Indonesia. The sport can be played from the level of children to adults (Hanafi, 2015). Volleyball is a sport played by two teams on a single field separated by a net. There are different versions of the number of players, the type or size of the field, the winning numbers used, for specific purposes (Irawan et al., 2021; Prakoso \& Setiyo Hartoto, 2015; Ramadan \& Hidayat, 2020). But in essence, the game of football intends to spread the playing skills to everyone who wants it (Ahmadi et al., 2020; Alminni et al., 2019; Ciccarone et al., 2005; Forte \& Altavilla, 2019; Häyrinen \& Blomqvist, 2006; Malikov et al., 2020; Molik et al., 2017; Pereira et al., 2015; Sheppard et al., 2007, 2008; WiÅsniowska et al., 2012). The goal of the ball game is to miss the ball over the net to fall to touch the floor of the opponent's field and to prevent the same effort from the opponent. Each team can play three bounces to return the ball. The ball is declared in the game after the ball is hit by the serviceman over the net into the opponent's area. The game continues until the ball hits the floor, the ball "comes out" or one team fails to return the ball perfectly and one of the players on the team commits a foul or fol, such as touching the net, touching the ball 2 times in a row and so on (Forte \& Altavilla, 2019; Malikov et al., 2020; Sheppard et al., 2007, 2008).

Jump service is done with the ball held with one or two hands. Once the ball is surpassed followed by jumping and trying the ball is above the front of the head. If the ball has been in front of the head then immediately the right hand is hit on the ball as soon as possible.

Achievement of high achievement in football requires several conditions (abilities) that must be met. In obtaining high achievements an athlete not only relies on his talent, but must have good physical, technical, tactical, and mental abilities. This is following the opinion of Soeharsono in Budhiono (2004: 255) that "in the aspect of sports achievement there are several aspects, one of which is the aspect of sports, which consists of: physical coaching, engineering, tactics, maturity of matches, coaches, training programs and evaluations"(Effendi, 2016; Irmansyah, 2017; Khamid, 2011; Et al., 2017; Constitution of the Republic of Indonesia no. 95, 2017). A volleyball game is a team game that requires various basic techniques in making it. Mastering the basic techniques of playing good football will make it easier for a player to carry out a strategy and high confidence and always optimistic in every game. Achieving a victory from every opponent faced is the main goal of the game of football. So, to get a victory in a match in a football game requires technique, good physical ability and tactics, and mental. Basic techniques as intended are service, passing, smash, and block. These techniques must be mastered to support.

As one of the leading private universities in Indonesia, The Muhammadiyah University of Surakarta also has a student activity unit of UMS Volleyball under the auspices of the All Indonesia Volleyball Association (PBVSI) Surakarta branch. UMS Student Activity Unit is centered at GOR Campus 2 UMS Jl. A. Yani. Tromol Pos I Pabelan, Kartasura, Surakarta 57102 and held a training at GOR campus UMS Surakarta. With the parent organization of PBVSI, in all matches and events regarding Volleyball, the Student Activity Unit (UKM) of Volleyball UMS always synergizes and collaborates with PBVSI, so that the implementation of all activities can run smoothly both in the field of organizing matches, referee training and 
even to training centers. The Muhammadiyah University of Surakarta itself has developed its ball game so that it often follows various matches and championships between universities held in the regional and national scope. From the results of field observations about the ability of the ball services of the son of the Student Activity Unit of the Muhammadiyah University of Surakarta is enough because of the matches that have been carried out, service is the most points gained in each match. The service carried out by Volleyball players of UMS student activity unit is mostly directed to the opponent's area whose passing ability is weak or to empty areas whose positions of the opponent's distance between his friends are far apart to make the opponent wrong to receive service and make the opponent's attack not carried out. Therefore, the author intends to research UMS student activity unit players on the analysis of the dominant factors determining the ability of service Volleyball. Based on the description above, researchers conducted a study with the title"Determinants of Volleyball Service Ability in Students of The Ums Volleyball Student Activity Unit" (Analysis of Confirmatory Factors Reviewed from Anthropometric and Physical condition Aspects).

\section{METHODS}

This study uses survey research using a quantitative descriptive approach using a design of confirmation analysis. This research was conducted at GOR Campus 2 UMS J1. A. Yani. Tromol Pos I Pabelan, Kartasura, Surakarta 57102. As for the implementation of this study in November 2021

\section{Participants}

The sample of this research is the sports education students of
Muhammadiyah University of Surakarta with the sex of male 1st semester totaling 40 people and the place of this research was carried out at Muhammadiyah University of Surakarta from December 2020 to January 2021.

\section{Sampling Procedures}

Sampling techniques use purposive sampling techniques. Because in this study are male students of sports education, Muhammadiyah University of Surakarta.

\section{Materials and Apparatus}

The design in this study is to use quantitative research design starting with data reduction, data verification data display, using the design factor confirmatory or often called confirmatory factor analysis (CFA). While in the analysis of confirmatory factors we look for some indicator variables that form variables that are not directly measured based on the existing theoretical basis.

\section{Procedures}

The techniques and tools of data collection or research instruments referred to in this study are devices used to collect data, namely: (1) To measure height using stature meters; (ii) To measure arm length using automatic measuring tape; (iii) To measure the length of the soles of the feet using a ruler; (iv) To measure the power of the limb muscles using a digital vertical jump test; (v) To measure eye-hand coordination using the tennis ball throwing test; (vi) To measure the malleability of the togok with a bridge-up test; (vii) To measure the strength of the abdominal muscles with a sit-up test; (viii) To measure the power of the arm and shoulder muscles with a two-hand medicine ball put to test; (ix) To measure kinesthetic perception using the Vertical Linear Space Test; and (x) To measure 
jump service capabilities with volleyball service tests.

\section{Design or Data Analysis}

Analisis data Data analysis used in this study is a technique of confirmatory factor analysis is a factor analysis technique that is a priori based on theories and concepts that are already known or determined before (Gudono, 2012). The data will be processed using the SPSS Version 20.0 program. The steps in analyzing confirmatory factors in this study are as follows:

1. Assumptions of Analytical Prerequisites

Before the process of data analysis using factor analysis methods, first conducted several statistical prerequisite tests, namely:

a. Normality Test

The normality test in this study used the One-Sample KolmogorovSmirnov Test method, processed using the SPSS Version 22 program.

b. Linearity Test

This test is used to see if the specifications of the model used are correct or not. The functions used in an empirical should be linear, squared, or cubic. For the regression linearity test in this study using the "Compare Mean" function, it was processed using the SPSS program version 22.

2. Factor Analysis and Hypothesis Testing

Analysis of factors in this study is used to explain the relationship between some independent changes with each other and to find out the dominant factors in explaining a problem. In this study, the free variables analyzed to find out the dominant factors determining the ability of jump service volleyball were height, arm length, length of leg, limb muscle power, abdominal muscle strength, arm muscle power, eye-hand coordination, togok flexibility, and kinesthetic perception. Hypothesis testing in this study was conducted by looking for the correlation coefficient of each predictor, regression equation $\mathrm{Y}$ over each predictor variable, regression equation $\mathrm{Y}$ overall predictor variables together with the double correlation coefficient. The calculations in hypothesis testing are as follows:

a. Kaiser-Meyer-Olkin and Bartlett's test of sphericity

KMO-MSA (KaiserMeyer-Olkin and Measure of Sampling Adequacy) numbers range from 0 to 1 which indicates whether the sample can be further analyzed or not. If the KMOMSA value is equal and greater than 0.5 and with a significant value (sig) or chance (p) smaller than 0.5 then it is said that the variables analyzed in the factor analysis are worthy of factoring.

b. Anti-image correlation test

The Anti-image correlation test is a correlation coefficient number that is on the diagonal (thickened value). If the value of the anti-image correlation matrix is less than 0.5 then the variable must be excluded or eliminated from the factor analysis (values marked with ${ }^{\text {a }}$ or thickened), so that the variable is not suitable for further analysis.

c. Total variance explained the test

The number of shared factors formed is as much as their constituent variables or dimensions. The factor, along with the total initial engine value $\geq 1$, represents the sub-variables that form them. The contribution of 
shared factors formed in the analysis can be seen from the total variance explained value.

d. Communalities or role factors

In commonality, the factors formed are a unity, so that the role or contribution of each subvariable is a constituent to the factors together. Valueinitial reflects the role or contribution that the constituent variables of factors individually form the factor, while extraction describes the percentage of roles or contributions of each dimension or sub-variable of the constituent factors individually to factors.

e. Component matrix (factor building dimension)

If the component value of the factor $\geq 0.5$ means that the dimension or sub-variable measurement of the factor is a member of the factor formed. Conversely, if the component value of a factor $<0.5$ means that the dimensions of the measurement sub-variable are not members of that factor.

f. Component score coefficient matrix or factor constituent dimension coefficient

Componenscore coefficient matrix emphasizes the form of relationships or models or equations between factors and their constituent variables. The coefficient score is a constant value similar to the regression coefficient $(\beta \mathrm{i})$ in the multiple regression equation.

\section{RESULT}

The research carried out refers to the stages of research as formulated in the research method. The results that have been achieved in this study are as follows
1. Descriptive analysis results

Descriptive analysis was conducted to draw in general related to dissemination of distribution of determinants of the ability of Volleyball service in students of the student activity unit of Muhammadiyah University of Surakarta (analysis of confirmatory factors in terms of anthropometry and physical condition). Recap the results of descriptive analysis of data can be seen images.

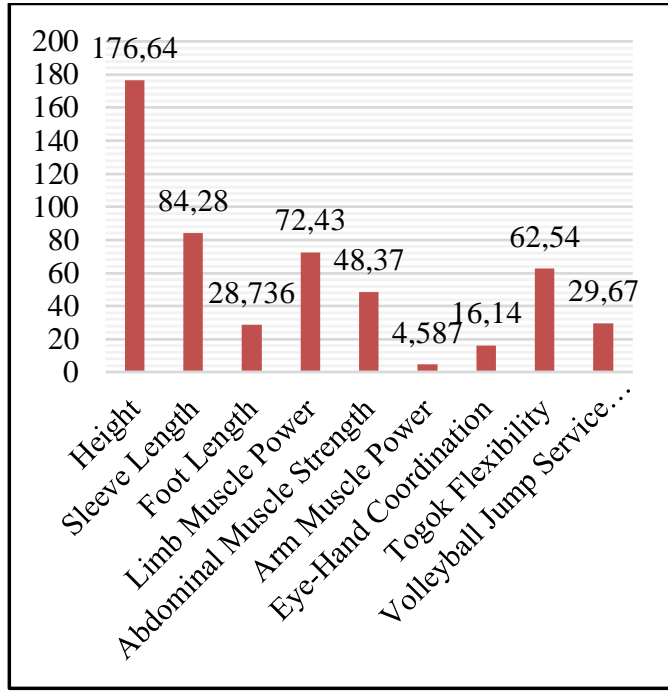

Figure 1. Histogram determining the ability of service Volleyball

Based on the results of the descriptive analysis in figure 1 histogram of student jump serviceability of 29.67 with good category. Thus it can be concluded that the determining factor of jump service Volleyball ability in the student male of the student activity unit of Muhammadiyah University of Surakarta (Analysis of Confirmatory Factors Reviewed from Anthropometric and Physical condition Aspects) greatly determines the ability of jump service in the game of Volleyball.

\section{Prerequisite test}

The normality test is used as a prerequisite for a hypothesis test. This normality test using the Kolmogorov- 
Smirnov Z (KS-Z) test can be seen in the following histogram image:

Table 2. Data normality test results

\begin{tabular}{lc}
\hline \multicolumn{1}{c}{ Variable } & $\begin{array}{c}\text { Asymp. Sig } \\
\text { (2-tailed) }\end{array}$ \\
\hline Height $\left(\mathrm{X}_{1)}\right.$ & 0.156 \\
\hline Arm length $\left(\mathrm{X}_{2)}\right.$ & 0.189 \\
\hline $\begin{array}{l}\text { Power of the limb } \\
\text { muscles }\end{array}$ & 0.200 \\
\hline $\begin{array}{l}\text { Abdominal muscle strength } \\
\left(\mathrm{X}_{4)}\right.\end{array}$ & 0.200 \\
\hline Arm muscle power $\left(\mathrm{X}_{5)}\right.$ & 0.193 \\
\hline $\begin{array}{l}\text { Eye coordination - hands } \\
\left(\mathrm{X}_{6}\right)\end{array}$ & 0.173 \\
\hline Togok 'spleness $\left(\mathrm{X}_{7)}\right.$ & 0.193 \\
\hline $\begin{array}{l}\text { Volleyball jump } \\
\text { serviceability }(\mathrm{Y})\end{array}$ & 0.171 \\
\hline
\end{tabular}

Based on the results of the data normality test on the normality test value table of the Muhammadiyah University of Surakarta (Confirmatory Factor Analysis Reviewed from Anthropometric and Physical condition Aspects) greatly determines the ability of jump service in the game of Volleyball in the entire data group turned out to be greater than the value of $\alpha=0.05$. Thus it can be concluded that this study sample comes from a normally distributed population. After the normality test, the hypothesis is tested.

\section{Hypothesis Test}

This study uses factor analysis as a constituent of a set of variable factors that have eligibility criteria for analysis. The determination of measurement variables has been determined before the analysis process. Broadly speaking, there are two measurement variables, namely anthropometric variables and physical condition variables. Anthropometric variables consist of height, arm length, and sole length of the feet. The physical condition variable consists of limb muscle power, abdominal muscle strength, arm muscle power, eye-hand coordination, togok flexibility, and kinesthetic perception. The analysis process uses the $\mathrm{R}$ Factor to find out the correlation between variables, then after obtaining the value of $\mathrm{R}$ Factor is done data reduction to get new variables that include several variables. Nine variables as the dominant factor determining the ability of jump service volleyball are then tested to find out whether all variables are dominant or just as variables that meet the eligibility to be analyzed and grouped into major factors. The following will be presented the results of the data analysis.

Table 3. KMO and Bartlett's Test results.

\begin{tabular}{ccr}
\hline \multicolumn{3}{c}{ Kaiser-Meyer-Olkin } \\
Measure of Sampling & 0.706 \\
\multicolumn{3}{c}{ Adequacy } \\
\hline Bartlett's & Approx. Chi- & \\
Test of & Square & 91.35 \\
Sphericity & Df & 21 \\
\cline { 2 - 3 } & Sig. & .000 \\
\hline
\end{tabular}

Based on the results of the analysis in the table above of 7 variables obtained the value of Kaiser-Meyer-Olkin Measure of Sampling Adequacy of 0.706 and the value of significance of 0.000 . If the Kaiser-Meyer-Olkin Measure of Sampling Adequacy value $>0.5$ and the significance value $<0.05$ then there is a strong relationship. The table above shows that the value of Kaiser-MeyerOlkin Measure of Sampling Adequacy is $0.706>0.5$ and the value of significance is $0.000<0.05$ so that it can be concluded that the 8 variable components in the study are declared significant and can be processed later. 
Table 4. Anti-image results matrices

\begin{tabular}{lc}
\multicolumn{1}{c}{ Variable } & $\begin{array}{c}\text { correlation } \\
\text { anti-image } \\
\text { matrices } \\
\text { correlation }\end{array}$ \\
\hline Height $\left(\mathrm{X}_{1)}\right)$ & 0.756 \\
\hline Arm length $\left(\mathrm{X}_{2)}\right.$ & 0.789 \\
\hline $\begin{array}{l}\text { Power of the limb } \\
\text { muscles }_{(\mathrm{X} 3)}\end{array}$ & 0.800 \\
\hline $\begin{array}{l}\text { Abdominal muscle } \\
\text { strength }\left(\mathrm{X}_{4}\right)\end{array}$ & 0.600 \\
\hline Arm muscle power $\left(\mathrm{X}_{5)}\right.$ & 0.893 \\
\hline $\begin{array}{l}\text { Eye coordination }- \text { hands } \\
\left(\mathrm{X}_{6)}\right.\end{array}$ & 0.773 \\
\hline Togok 'spleness $\left(\mathrm{X}_{7}\right)$ & 0.693 \\
\hline
\end{tabular}

The results of the analysis in the anti-image matrices correlation table showed that the seven variables namely height has a value of 0.756 , arm length has a value of 0.789 , limb muscle power has a value of 0.800 , abdominal muscle strength has a value of 0.600 , arm muscle power has a value of 0.893 , and togok flexion has a value of 0.693 . Value of the seven variables has a Measure of Sampling Adequacy value $>0.5$.

To find out the contribution of each variable in each component of the analysis of the determinant of the ability of jump service Volleyball in the student male of the student activity unit of Muhammadiyah University of Surakarta (Analysis of Confirmatory Factors Reviewed from Anthropometric and Physical condition Aspects), a rotation process is carried out to result in the component matrix that will be presented in the following table.

Table 5. Rotated component matrix results

\begin{tabular}{lcc}
\hline \multirow{2}{*}{\multicolumn{1}{c}{ Variable }} & \multicolumn{2}{c}{ Component } \\
\cline { 2 - 3 } & $\mathbf{1}$ & $\mathbf{2}$ \\
\hline Height $\left(\mathrm{X}_{1)}\right.$ & 0.856 & 0.364 \\
\hline Arm length $\left(\mathrm{X}_{2)}\right.$ & 0.889 & 0.256 \\
\hline $\begin{array}{l}\text { Power of the limb } \\
\text { muscles }\end{array}$ (X3) & 0.678 & 0.341 \\
\hline
\end{tabular}

\begin{tabular}{lcc}
\hline \multicolumn{1}{c}{ Variable } & \multicolumn{2}{c}{ Component } \\
\cline { 2 - 3 } & $\mathbf{1}$ & $\mathbf{2}$ \\
\hline $\begin{array}{l}\text { Abdominal muscle } \\
\text { strength }\left(\mathrm{X}_{4}\right)\end{array}$ & 0.687 & 0.230 \\
\hline $\begin{array}{l}\text { Arm muscle power } \\
\left(\mathrm{X}_{5)}\right.\end{array}$ & 0.875 & 0.258 \\
\hline $\begin{array}{l}\text { Eye coordination - } \\
\text { hands }\left(\mathrm{X}_{6}\right)\end{array}$ & 0.856 & 0.259 \\
\hline $\begin{array}{l}\text { Togok 'spleness } \\
\left(\mathrm{X}_{7}\right)\end{array}$ & 0.863 & 0.367 \\
\hline
\end{tabular}

Based on the results of rotated component matrix determining factor in the ability of jump service Volleyball in the student male of the student activity unit of the Muhammadiyah University of Surakarta (Analysis of Confirmatory Factors Reviewed from Anthropometric and Physical condition Aspects) can be described as follows:

a) The height factor has a variable correlation value of factor 1 by 0.856 and factor 2 by 0.364 . Because the correlation value of factor $1>$ the correlation value of factor 2 then height includes a group of factors 2 .

b) The arm length factor has a variable correlation value of factor 1 by 0.889 and factor 2 by 0.256 . Because the correlation value of factor $1>$ the correlation value of factor 2 then arm's length belongs to the group of factors 2 .

c) The power factor of the limb muscles has a variable correlation value of factor 1 by 0.678 and factor 2 by 0.341 . Because the correlation value of factor $1>$ the correlation value of factor 2, the power of the limb muscles belongs to the group of factors 2 .

d) The abdominal muscle strength factor has a variable correlation value of factor 1 of 0.687 and factor 2 of 0.230 . Because the correlation value of factor $1>$ the correlation value of factor 2 then the strength of the abdominal muscles belongs to the group of factor 2 . 
e) The power factor of the arm muscle has a variable correlation value of a factor of 1 by 0.875 and a factor of 2 by 0.258 . Because the correlation value of factor $1>$ the correlation value of factor 2 , arm muscle power belongs to the group of factors 2 .

f) The eye-hand coordination factor has a variable correlation value of factor 1 by 0.856 and factor 2 by 0.259 . Because the correlation value of factor $1>$ the correlation value of factor 2, arm muscle power belongs to the group of factors 2 .

g) The togok flexibility factor has a variable correlation value of factor 1 by 0.863 and factor 2 by 0.367 . Because the correlation value of factor $1>$ the correlation value of factor 1, height includes group factor 2

\section{DISCUSSION}

Based on the results of the above hypothesis test about the analysis of anthropometric and physical condition factors determining jump serviceability in the unit of student activities the volleyball Muhammadiyah University of Surakarta it is known that there are 2 physical condition variables, namely eye-hand coordination factors and kinesthetic perception that do not meet the feasibility and must be carried out the elimination process because it has a measure of sampling adequacy. $>0.5$. while the other 7 variables, namely height, arm length, limb muscle power, abdominal muscle strength, arm muscle power,eyehand coordination, and togok flexibility meet very determine the speed of jump service volleyball.

The dominant anthropometric actor in determining the ability of volleyball jump service is the arm length with a value of 0.889 and height with a value of 0856 . Fphysical condition actors who are dominant in determining the ability of jump service volleyball is the power of the limb muscles with a value of 0 . 678, power the arm muscles with a value of 0.875 , a togok with a value of 0 . 863 , hand-eye coordination 0.856 , and abdominal muscle strength with a value of 0 . 687. Based on the results of the second analysis obtained the result that the seven variables have communalities values $>0.5$. So that can be concluded that the greater the communalities value of these factors will give benefits to male students in the student activity unit of the Muhammadiyah University of Surakarta in doing jump service Volleyball.

The results of $\mathrm{Z} \&$ Firdaus Research, (2020) concluded that the physical condition possessed by athletes consists of aerobic endurance, arm muscle explosiveness, limb muscle explosiveness, and the flexibility of the average waist muscle belongs to the category of sufficient. From the results of this study, the need for the physical condition of athletes has improved again through a training program that has been systematically arranged to achieve even better achievements later.

Research (Suhdy, Ever, 2019) produces physical condition is a very important element in every sport, physical condition plays a very important role to determine achievement in sports. Therefore, the readiness of physical conditions is very important to be able to support the technical ability of club footballers in the city of Lubuklinggau better. Thus, the level of the physical condition of caroline club footballers and JVC club of Lubuklinggau city that is owned now needs to be improved again by conducting a planned and systematic training process and implemented continuously and continuously to produce the better physical condition.

Research conducted by Setiyawan et al., (2021) that 1) the jump service 
technique model following the principle of jump service practice, 2) the model is effective to improve jump service capabilities, 3) the model is feasible and ready for mass use. produced as a guideline in carrying out the training process, especially for jump service.

Research conducted Setiyawan et al., (2021) that anthropometric factors and physical condition factors that determine the ability of volleyball jumping services in male athletes in the student activity unit uns consists of seven factors namely height, arm length, leg length, limb muscle power, abdominal muscle strength, arm muscle power, and flexibility.

Every sport requires

anthropometric requirements that every athlete must have to be able to achieve high achievements. as well in the game of volleyball demands ideal anthropometry. having ideal anthropometry will support the mastery of the ability to play volleyball. anthropometric factors are dominant in the ability of jump service Volleyball, among others, variable height, and arm length. Furthermore, for the physical condition factors in this study that predominantly determine jump service volleyball namely limb muscle power, abdominal muscle strength, arm and shoulder muscle power, eye-hand coordination, and togok flexibility. Therefore that jump service is a service with a prefix and how to hit almost the same as the top service, but done by jumping or floating. the first shot done by jumping is a blow that is relatively difficult to master even though many players try to do it.

\section{CONCLUSION}

Therefore it can be concluded that anthropometric factors and physical condition factors that determine the ability of jump servicinge volleyball in male athletes in the student activity unit of the Muhammadiyah University of Surakarta consist of seven factors, namely height, arm length, limb muscle power, abdominal muscle strength, arm muscle power,eye-hand coordination, and togok flexibility. However, this study is only limited to the group of prince samples, for further research it is advisable to involve the sample of princesses and social environmental factors and those associated with increased jump service Volleyball.

\section{ACKNOWLEDGEMENT}

Thank you to the Muhammadiyah University of Surakarta for allowing researchers to research the determining factors of jump service volleyball ability in the student male of the student activity unit of Muhammadiyah University of Surakarta (analysis of confirmatory factors reviewed from anthropometric and physical condition aspects) through individual research lecturers fiscal year 2021.

\section{REFERENCES}

Ahmadi, S., Gutierrez, G. L., \& Uchida, M. C. (2020). Correlation between handgrip and isokinetic strength of shoulder muscles in elite sitting volleyball players. Journal of Bodywork and Movement Therapies. https://doi.org/10.1016/j.jbmt.2020.07.0 15

Alminni, C., Isanto, T. D., Elia, F. D., \& Altavilla, G. (2019). Test of the Jump Service Spin in Volleyball. Sport Mont, 17 , 105-108. https://doi.org/10.26773/smj.191010

Effendi, H. (2016). Peranan Psikologi Olahraga Dalam Meningkatkan Prestasi Atlet. Nusantara (Jurnal Ilmu Pengetahuan Sosial. https://doi.org/http://jurnal.umtapsel.ac.id/index.php/nusantara/article/ view/90/90 
Forte, D., \& Altavilla, G. (2019). Original Article Preliminary correlation between anthropometric and performance data in volleyball about the transition period JPES ®. Journal of Physical Education and Sport, 5, 1994-1998. https://doi.org/10.7752/jpes.2018.s5296

Hanafi, S. (2015). Efektifitas Latihan Beban dan Latihan Pliometrik Dalam Meningkatkan Kekuatan Otot Tungkai dan Kecepatan Reaksi. Jurnal ILARA, $1(2), 32-35$.

Irawan, B., Muhyi, M., \& Wiyarno, Y. (2021). Pengembangan Permainan Kasvol Terhadap Minat Siswa Untuk Bermain Bolavoli Saat Pembelajaran PJOK Pada Siswa Kelas VI MI Baiturrahman Kedurus Surabaya. Jendela Olahraga. https://doi.org/10.26877/jo.v6i1.6766

Irmansyah, J. (2017). Evaluasi program pembinaan prestasi cabang olahraga bola voli pantai. Jurnal Keolahragaan. https://doi.org/10.21831/jk.v5i1.12759

Khamid, A. (2011). Kemampuan awal, minat olahraga, dan prestasi belajar olahraga. Jurnal Ilmu Pendidilkan, 17(no4), 265269.

Laksana, G. B., Pramono, H., \& Mukarromah, S. B. (2017). Journal of Physical Education and Sports Perspektif Olahraga Petanque dalam Mendukung Prestasi Olahraga Jawa Tengah Abstrak. 6(1), 36-43.

Malikov, N., Konoh, A., \& Korobeynikov, G. (2020). Original Article Physical condition improvement in elite volleyball players. Journal of Physical Education and Sport, 20(5), 2686-2694. https://doi.org/10.7752/jpes.2020.05366

Molik, B., Morgulec-Adamowicz, N., Marszałek, J., Kosmol, A., Rutkowska, I., Jakubicka, A., Kaliszewska, E., Kozłowski, R., Kurowska, M., Ploch, E., Mustafins, P., \& Gómez, M. Á. (2017). Evaluation of game performance in elite male sitting volleyball players. Adapted Physical Activity Quarterly. https://doi.org/10.1123/apaq.2015-0028

Pereira, A., Costa, A. M., Santos, P., Figueiredo, T., \& João, P. V. (2015). Training strategy of explosive strength in young female volleyball players. Medicina

(Lithuania). https://doi.org/10.1016/j.medici.2015.0 3.004

Prakoso, D. P., \& Setiyo Hartoto. (2015). Pengukuran Tingkat Kebugaran Jasmani Terhadap Siswa Yang Mengikuti Ekstrakulikuler Bolavoli di SMS DR.Soetomo Surabaya. Jurnal Pendidikan Olahraga Dan Kesehatan. https://doi.org/10.1098/rstb.2014.0015

Ramadhan, R. S., \& Hidayat, T. (2020). Pengaruh Reinforcement Negatif dan Positif Terhadap Motivasi Siswa Dalam Pembelajaran Servis Atas Bolavoli. Jurnal Pendidikan Olahraga Dan Kesehatan, 8(1), 301-305. https://jurnalmahasiswa.unesa.ac.id/ind ex.php/jurnal-pendidikanjasmani/article/view/35309

Setiyawan, A. A., Kristiyanto, A., \& Purnama, S. K. (2021). Factors Determining the Ability of Jump Volleyball Providing. Health, Sport, Rehabilitation, 7(1). https://doi.org/https://doi.org/10.34142/ HSR.2021.07.01.05

Suhdy, Ever, S. M. S. M. (2019). Kondisi Fisik Pemain Bola Voli Klub Di Kota Lubuklinggau. Gelanggang Olahraga: Jurnal Pendidikan Jasmani Dan Olahraga, $2, \quad 13-25$. https://doi.org/https://doi.org/10.31539/ jpjo.v2i2.697 KONDISI

UUD Republik Indonesia no 95. (2017). Peraturan Presiden Republik Indonesia Tentang Peningkatan Prestasi Olahraga Nasional. 15. setkab.go.id/wpcontent/uploads/2017/10/Perpres-

Nomor-95-Tahun-2017.pdf

WiÅıniowska, M., Tasiemski, T., \& Bauerfeind, J. (2012). Athletic Identity Assessment in Disabled Sitting Volleyball Players. Physiotherapy / Fizjoterapia.

Z, A. A., \& Firdaus, K. (2020). Tingkat Kondisi Fisik Atlet Bolavoli Putra Padang Adios Kota Padang. Jurnal Pendidikan Olahraga, 3(5). 